\title{
The Post-2015 Debate and the Place of Education in Development Thinking
}

Simon McGrath, University of Nottingham and University of KwaZulu-Natal, simon.mcgrath@nottingham.ac.uk

As the end date for the Millennium Development Goals (MDGs) approaches so the focus on goals, visions and policies for development after 2015 becomes ever heightened. However, there has been relatively little engagement by educational research community in these debates. Indeed, a former UNESCO Assistant Director-General for Education, Nick Burnett, has warned about the dangers of education's perceived "irrelevance" for post-2015 debates (Burnett 2012). What then is being written about education in the key post-2015 documents? How is education's role in development conceptualised by those most central to shaping new accounts? Through an analysis of a key text on post2015, the High Level Panel Report of May 2013 (UN-HLP 2013), and an exploration of a year's worth of posts on 30 prominent blogs and websites discussing post-2015 matters ${ }^{1}$, I seek to explore these issues. This leads me to two further, interlinked questions: what are the implications of potential marginalisation and irrelevance from these debates for the field of international education and development research? What are the potential dangers for the field of closer engagement in these debates, including participation in the dominant modalities of tweets and blogs?

The most prominent international education and development conferences, those of the United Kingdom Forum for International Education and Training (2013) and the (North American) Comparative and International Society (2014) have both identified the need for the international education and development research community to engage seriously with the post-2015 debates but the lateness of these events in the post-2015 policy cycle are indicative of a slowness of response. Even at this late date, and remembering the importance of the period after any new goals are agreed, the international education and development research community needs to decide whether to engage more seriously with the post-2015 process. In doing so, it can take a number of stances, ranging from that of critics standing outside the process, through constructive engagers and to partisans advocating for their particular issue's "day in the sun". Our choices amongst these positions affect who we talk to, what we say, what methods and evidence we use, how we seek funding and, ultimately, the health of the field.

Before going further it is necessary to spend a few moments reflecting on a couple of terms that I have used in those first two paragraphs: community and field. In my attempt to set the scene quickly I have used these as if they are unproblematic. Yet, of course, that is far from the case. The extent to which international education and development could be said to exist as a field separate from (international and) comparative education is a matter for debate (cf. Crossley and Watson 2003; Crossley, Broadfoot and Schweisfurth 2007). Moreover, the notion of a community underplays the very different epistemological and methodological positions that characterise its sociology and economics "wings"; its academic and practical tendencies; and different national traditions as well as the very significant effects of being either Northern or Southern participants in debates.

I also need to reflect briefly on some further philosophical and methodological issues that lurk behind this article. First, in discussing the interplay between debates about development policy and the international education and development field, the project assumes a close relationship between development goals and development theory that is far from simple. In their nature, development goals, the focus of the post-2015 debates, are political, consensus-based and non-specialist derived. They are based in implicit theories-in-use (Argyris and Schön 1974) and are only very loosely evidence-based, in

\footnotetext{
${ }^{1}$ See the references for a list of these.
} 
spite of the rhetoric surrounding them (King and Palmer 2013). As Vandermoortele (2011) reminds us, there is an inevitable tension between pragmatic sets of goals, and the texts designed to advocate for and advance them, and any overarching theories of development. Goals development, moreover, cannot be separated from technical discussions about what is amenable to measurement and how, and the availability and improvability of datasets. Moreover, development policy and development theory are characterised by different sets of subjects and objects. Importantly, the rise of social media means that much of the debate around the goals is taking place through new communications modalities such as twitter and infographics, with their own logics of communication and their own truth regimes.

Second, and following on from this last point, it is important to note briefly the very different possibilities and challenges of researching the evolution of the post-2015 goals as opposed to development texts of previous eras. ${ }^{2}$ In 2004, King and I noted the effects of the rise of the internet in researching development thinking (King and McGrath 2004). For the current study, however, it is the rise of social media that has been central. Whilst there is still crucial work being done in closed meetings of experts and/or politicians, much more of the debate leading up to 2015 has been in the public domain. To follow this has necessitated more than trawling websites, however. Rather, it has required bringing more traditional data gathering skills to bear on use of twitter and blogs in seeking to identify both the key voices and messages of broader post-2015 debates. This has led to (almost) daily time on twitter, reading the posts of those who appear to be influential actors, exploring their interactions with other twitter users and following links to blogs, websites and documents to which they point. It has also involved identifying a range of blogs, through the above methods but also through examining the links that others recommend and by following my nose regarding which organisations are significant to the debate. This requires an interesting traversing of the boundary between the institutional and the personal, with some of the blogs being written in personal capacities but being of potential importance because of the institutional positions of their authors; others being on official sites but "not official positions" ${ }^{3}$ and others still officially representing organisational positions and identities. Such a process is necessarily about adopting a snowballing technique and hoping that rigorous pursuit of leads can bring about representative coverage of points and positions. However, scientific levels of representivity are not possible in such an approach. The list of 30 key blogs and websites (all studied for the whole of 2013) at the end of the paper points to the scale of the task involved in such a study.

Third, the timing of this article also is crucial to reading it. It was written just after a wave of post-2015 reports had been published between the end of May and middle of July 2013. Most prominent of these, and the focus of this paper, was the High Level Panel Report (UN HLP 2013) but this was closely followed by the reports of the Open Working Group on Sustainable Development Goals (OWG-SDG 2013); the Sustainable Development Solutions Network (SDSN 2013); UN Global Compact (UN Global Compact 2013) and the UN Secretary General (UN 2013).

The conference paper on which it is based was presented immediately prior to the UN General Assembly's discussions of the MDGs and what comes after. At the time of reworking as a journal article, the High Level Panel report was still the most significant official output of the post-2015 processes and this is the text that blogs and papers of 2013 were either anticipating or reacting to. Inevitably, this gives the paper a very different flavour than one written at another point in the process, including in the time period that will elapse before the article is finally published.

\footnotetext{
${ }^{2}$ See King 1990 for a detailed analysis of the emergence of the key documents of the World Conference on Education for All.

${ }^{3}$ Whilst we reflected in King and McGrath (2004) about the tensions between the possibilities of more pluralist international development agency positions against tight corporate communications control as websites proliferated; it appears that the rise of social media has shifted a number of agencies into more decentralised modes of public engagement. See, for instance, the presentation of work from World Bank staff through its blog offerings- http://blogs.worldbank.org/.
} 
In what follows, I will consider four questions in turn as a way of structuring the subsequent sections:

- What do the current post-2015 debates suggest about theories of development?

- Is the account of education in these debates satisfying?

- What are the policy challenges for education in the post-2015 debate?

- What are the implications of these debates for the future of international education and development as a field of study?

\section{What do the current post-2015 debates suggest about theories of development?}

Before turning my full attention to the post-2015 debates, it is important to reflect back to what the MDGs suggest about theories of development. According to one of the MDGs architects:

the MDGs were meant to broaden the development narrative beyond the narrow growth paradigm. ... [but] the search for a broader interpretation of development has failed. The MDGs have been misconstrued and distorted to make them fit with the orthodox policy framework. As a result, the global debate remains dominated by the implicit formula: faster economic growth+more foreign aid+better governance=MDGs. (Vandermoortele 2011: 13)

Vandermoortele's hinting at the failure to imbue the MDGs with a human development flavour is significant. Whilst there has been a strong tendency to argue that the MDGs are about some of Nussbaum's foundational capabilities (Nussbaum 2001), it seems more plausible to see the MDGs as a compromise between the Neoliberalism of the Washington Consensus and human rights approaches.

How then does the HLP Report offers a meaningful response to Vandermoortele's summary of the critiques of the MDG approach:

The basic criticism against the Millennium Development Goals (MDGs) is that they represent a reductionist view of development. They are too limited in scope; their definition is too narrowly focused on the social sectors; their sectoral fragmentation leads to vertical silos; their emphasis on quantification is excessive; and that they omit fundamental objectives contained in the Millennium Declaration, such as peace and security, human rights, democracy and good governance, and the protection of the most vulnerable. The criticism also points out that they fail to underscore universal values such as freedom, tolerance and equality. Too many dimensions of development are missing (e.g., human rights and economic growth) and they inadequately address the complexity of the dimensions that are included (e.g., gender equality and the quality of freedom). (Vandermoortele 2011: 9) ${ }^{4}$

On the positive side, the HLP goals can be argued to be less reductionist that the MDGs. There is a far stronger balance of economic and social dimensions and a wider range of themes are included in the list of goals:

1. End Poverty

2. Empower Girls and Women and Achieve Gender Equality

3. Provide Quality Education and Lifelong Learning

4. Ensure Healthy Lives

5. Ensure Food Security and Good Nutrition

6. Achieve Universal Access to Water and Sanitation

7. Secure Sustainable Energy

\footnotetext{
${ }^{4}$ Vandermoortele is here summarising a position with which he only partially agrees.
} 
8. Create Jobs, Sustainable Livelihoods and Equitable Growth

9. Manage Natural Resource Assets Sustainably

10. Ensure Good Governance and Effective Institutions

11. Ensure Stable and Peaceful Societies

12. Create a Global Enabling Environment and Catalyse Long-Term Finance

However, can the HLP Report be seen as a radical shift that it seeks to project? Its own rhetoric is a mix of "business as usual" - in the sense that the MDGs were a valuable and successful project - and a "transformative shift" - according to a recurrent phrase of the HLP document. There certainly are a broader range of themes considered worthy of inclusion in the high level goals, although much of this was contained already in the larger Millennium Declaration and in the MDG sub-goals. Yet, even the stronger sustainable development focus is relatively limited. As I wrote in my own first blog response in early June:

what does its use of the phrase "sustainable consumption and production" really amount to? It appears, for instance, that the lifestyles of the rich can be maintained as there is no inherent tension between this and growth in the South (8). Is there real appetite to address unsustainable consumption, given the likely political costs entailed? Equally, the Report talks of rapid, inclusive and sustainable growth, but there are many who would question whether this is possible. (McGrath 2013)

Moreover, the dilution of the notion of "decent work" is particularly worrying.

There is little sense still of the insights provided by the capability approach, so influential in academic debates; or the range of thinking about complexity and systems thinking that pervade much of the development blogosphere (cf. aspects of the blogs at www.owen.org/blog, www.comparativist.org and www.oxfamblogs.org/fp2p). Rather, the tendency seems to be towards simple goals that can bring together a range of constituencies and achieve some compromise between growth, poverty and sustainability concerns.

In spite of the weight of criticisms of the MDGs as being too focused on the global level, the official post-2015 agenda appears resistant to alternatives such as that outlined by Hulme and Wilkinson:

Perhaps the post-2015 global development goals approach should seek to catalyse enhanced national debates and discussions and examination of evidence that strengthens national plans, policies, budgetmaking and implementation. Rather than global goals being a neat set of goals in a UN document, global goals would be the totality of national development goals knitted together through their commitment to multiple ways of tackling destitution. (Hulme and Wilkinson 2012: 12)

As I have already noted elsewhere (McGrath 2013) there is insufficient articulation between the various goals presented in the HLP Report, which still appear largely stuck in sectoral silos. Equally, the interconnectedness of global meta-goals; international sectoral goals and national development goals remains unclear.

Here I have focused primarily on the HLP process and it must be remembered that here are other strands to the post-2015 debate. Some, such as the OWG, focus much more strongly on sustainability, but it seems that 2013 saw a rising acceptance that there will be a set of global goals that will be broader than the MDGs but which will require compromises between poverty, growth and sustainability agendas. 


\section{Is the account of education in these debates satisfying?}

Those readers who know my work can anticipate the answer to this, which can also probably be discerned from my treatment of the MDGs and the HLP Report above. What then is the account of education present in the post-2015 debates?

Within the overall post-2015 debates, the answer is a rather contradictory one. On the one hand, the MyWorld survey shows that education is the number one priority amongst the more than one million respondents (www.myworld2015.org). Education also appears on most of the goal lists that have been produced so far and seems likely to be found in any final set of post-MDGs. Yet, I have already noted that Burnett has argued that there is a real danger of education's irrelevance in the current debate. What appears to be the case is that amongst the "expert" development community, education is not a major focus. As I wrote when reviewing major development books a few years ago (McGrath 2010), education hardly features in mainstream accounts of development and, when it does, the understanding of education is deeply problematic. It is extremely instrumental, seeing education as a means towards greater goals such as gender equality, population control and democracy. It frequently is technologically utopian, believing that education is as simple to achieve as distribution of oral rehydration salts or mosquito nets.

This is exacerbated by the educational debate about post-2015 to date. Within the academic educational community, there has been relatively little engagement until very recently (see Barrett 2011 for a rare exception ${ }^{5}$ ). Rather, engagement has come from a set of thinktanks and networks: the UNESCO Global Monitoring Report team (www.efareport.wordpress.com) ${ }^{6}$; the Centre for Universal Education at the Brookings Institution (www.brookings.edu/blogs); the Global Partnership for Education (www.educationforallblog.org) being most prominent ${ }^{7}$. The domination of the educationfor-development public debate by these voices has had significant effects. All are very much in advocacy mode, determined to show the value of education for development in order to ensure its position in the post-2015 goal architecture.

Those lobbying for education's inclusion in the post-2015 goals argue for a large set of developmental impacts for education. ${ }^{8}$ Adams, from Brookings, exemplifies this with a large set of claims in a paper subtitled "Why learning is central to the post-2015 global development agenda". In this, it is argued that education:

- increases wages, leading to reduced poverty

- reduces vulnerability to shocks

- reduces inequality

- increases employability

- improves life skills for participation in society

- improves reproductive health

- reduces fertility, leading to population sustainability

- raises civic awareness and political participation

- improves social integration and cohesion

- increases productivity

- enhances political stability

- reduces criminality (Adams $2012^{9}$ )

\footnotetext{
${ }^{5}$ Although this was written as part of a DfID-funded research programme.

${ }^{6}$ Here I am treating the GMR as a thinktank / advocacy agency that is largely autonomous from UNESCO in terms of its freedom and speed of response to international debates. King and Palmer (2013) provide a valuable account of the centrality of the GMR team to the educational aspects of the post-2015 debate. 7 Here I have referenced their blogs but many of the advocacy twitter feeds are also highly prominent: the Global Campaign for Education (@global education) had 25,000 followers at the end of 2013; the Global Partnership (@GPforEducation) nearly 27,000; GMR (@EFAReport) 8,000.

${ }^{8}$ See King and Palmer (2013) for a detailed analysis of these claims and their evidential basis.

${ }^{9}$ See CRWBL 2006 for similar work in a developed country context.
} 
As Yusuf Sayed noted in summarising debates at the 2013 Dakar Global Meeting on Education in the Post-2015 Development Agenda:

education is key for development, with stakeholders stressing that it, inter alia: is a basic human right; underpins many other development priorities; and is the most effective means to overcome inequality, eradicate poverty and achieve development. (quoted in International Institute for Sustainable Development 2013)

Lists such as that extracted from Adams lack robust evidence from Southern contexts to back up many of the claims being made. Typically such lists of effects are very lightly referenced and often those references which are given are to agency reports that often oversimplify or distort the original research findings, which were typically localised in time and/or spaceuy. They ignore context and provide spurious mean values derived from studies spread over time, space and methods (cf. King, Palmer and Hayman 2005; King and Palmer 2013). Whilst Sayed summarises very elegantly the consensus of educational activists, unsurprisingly there is no sense of the contestations that exist between these multiple visions of education.

The rise of social media has exacerbated this tendency to crystallise complex educational messages into simplistic slogans. Blogs need to be punchy, but the rise of the infographic and the tweet force writers to focus on key phrases and statistics that undermine any comparative education concerns about context and complexity. Below I will examine the central position given in the HLP presentation of education to a 2004 paper by Psacharopoulos and Patrinos. Both in the run up to the HLP Report and in the subsequent six months, one statistic from the paper became the central message of a twitter campaign about education's development value: one year of education increases lifetime earnings by $10 \%$. I will raise some of the questions about the value of this statement below, but one of its effects in the post-2015 education and development debate is to drive a wedge between an activist position, for which it is a powerful fact that potentially guarantees education's place in the post-2015 sun, and an academic one that struggles to get past a series of problems with a statement like this, which they would largely see as false.

This is but the most powerful of a set of soundbites coming from the education advocates, as a handful of tweets from @EFAReport illustrate:

"The odds of children carrying malaria is $1 / 3$ rd lower if their mothers have a secondary education than if their mothers have no education"

"Every $\$ 1$ spent on education generates \$10-15 in economic growth"

"If all students in low income countries left school with basic reading skills, it would result in almost $1 / 7^{\text {th }}$ cut in world poverty"

"One additional year of maternal education would decrease child deaths from pneumonia by $14 \% "$

The issues here are difficult. Academic educationalists are generally highly committed to a belief in the value of education as a means of improving individuals' lives. The advocates are undoubtedly doing much to guard against Burnett's warning about education's irrelevance to development. However, there is a need to question whether some of the messages being generated about education's impacts are sufficiently wellgrounded in evidence. It is clear that some (cf. King, Palmer and Hayman 2005) are derived from limited and dated studies and are being cherry-picked to make a point. Moreover, there are questions as to the epistemological, ethical and ideological approaches underpinning attempts to reduce education's value to a series of such "killer facts". Moreover, whilst the debate has supposedly shifted towards a greater focus on achieved learning rather than years of education, few of these slogans escape from the seductive simplicity of years of schooling (but see the claim regarding poverty and reading). 


\section{Education in the HLP Report}

How then have these arguments been taken up in the HLP Report? I will analyse this in three ways. First, I will consider the goal and subgoals for education suggested in the HLP Report. Second, I will examine how these are justified in Annexe 2 of the Report. Third, I will explore what the overall text says about education as part of development.

First, let us look at the goal text: "quality education and lifelong learning". This is an advance on the MDGs, but not the Education for all (EFA) goals. Indeed, both quality and lifelong notions were very clearly part of the language used at Jomtien. For instance, as King and Palmer (2012) remind us, the Jomtien Declaration was very clear that just getting children into school would not result in development:

\section{Whether or not expanded educational opportunities will translate into meaningful development - for an individual or for society - depends ultimately on whether people actually learn as a result of those opportunities, i.e., whether they incorporate useful knowledge, reasoning ability, skills and values. (UNESCO, WCEFA, Declaration, 1990: 5. Emphasis in original)}

Second, this goal is supported by four sub-goals:

a. Increase by $\mathrm{x} \%$ the proportion of children able to access and complete preprimary education

b. Ensure every child, regardless of circumstance, completes primary education able to read, write and count well enough to meet minimum learning standards

c. Ensure every child, regardless of circumstance, has access to lower secondary education and increase the proportion of adolescents who achieve recognised and measurable learning outcomes to $\mathrm{x} \%$

d. Increase the number of young and adult women and men with the skills, including technical and vocational, needed for work by $\mathrm{x} \%$ (UN HLP 2013: 30).

Additionally, education is mentioned in one of the jobs sub-goals:

$8 \mathrm{~b}$. Decrease the number of young people not in education, employment or training by $\mathrm{x} \%$ (UN HLP 2013: 31).

Again, it is possible to be positive about all this. Education gets a goal and sub-sectors such as early childhood development, secondary schooling and vocational education and training all get attention in sub-goals, although literacy and higher education are absent (cf. King 2013; McGrath 2013). Thus some of the reductionism of the MDGs on education is avoided, although, again, we need to be cautious and remember what happened after Jomtien. This may include reflecting on how the broader vision of the World Declaration came to be narrowed down in the first place, and what implications this might have for the post-2015 goals. As a number of posts on the Norrag blog in particular have noted, these sub goals are still weak conceptually and have severe problems with measurability. The skills sub-goal does nothing to suggest that there has been learning regarding the disaster of EFA Goal 3 with its failure to conceptualise what it means by skills or to develop an effective measurement strategy. The globalisation of the NEET concept in $8 \mathrm{~b}$ is also seriously problematic, as both King and I have noted on the Norrag blog. 
Second, I want now to look at the two pages in Annexe 2 on education (36-7). Let us start with the first paragraph, which repeats many of the classic claims about the education-development relationship, and which draws heavily on work by Brookings (2013):

Education is a fundamental right. It is one of the most basic ways people can achieve wellbeing. It lifts lifetime earnings as well as how much a person can engage with and contribute to society. Quality education positively effects health, and lowers family size and fertility rates. Availability of workers with the right skills is one of the key determinants of success for any businessand of capable and professional public bureaucracies and services. Investing in education brings individuals and societies enormous benefits, socially, environmentally and economically. But to realize these benefits, children and adolescents must have access to education and learn from it. (UN HLP 2013: 36)

The second paragraph opens, however, with any sense of quality or rights abandoned in favour of an increasingly instrumentalist argument that is based soundly in rates of return analysis and a simplistic interplay between years of schooling and formal sector earnings. Here we see the HLP accept the $10 \%$ claim that had been so powerfully pushed by the education lobbyists:

Across the world, investment in education clearly benefits individuals and societies. A study of 98 countries found that each additional year of education results in, on average, a 10 per cent increase in lifetime earnings - a huge impact on an individual's opportunities and livelihood. (UN HLP 2013: 36)

As was noted above, this figure comes from Psacharopoulos and Patrinos (2004) and is followed on the next page with the reproduction of a figure from their 2002 version of the same paper. Remarkably, this figure takes up approximately one-quarter of all the space devoted to education. This is in spite of it not really have much salience to the argument of the goals, which are not seeking to distinguish between the developmental effects of different levels of education ${ }^{10}$, nor to make the narrow case that education's developmental effects consist of impact upon earnings. Neither does it make much sense as the core of an argument that learning matters rather than notional years of schooling. Rather, it appears that the argument for education in the HLP Report is built on a shaky foundation, with the education text appearing radically different from the core messages of the HLP on education and livelihoods or on transformative shifts in development policy and practice more generally.

Third, education is also mentioned in a few places elsewhere in the HLP Report (see Carton 2013 for a content analysis). As Goal 3b exemplifies, there are signs of a strong youth unemployment agenda in the HLP Report, reflecting the strong messages of the GMR 2012, MyWorld (www.myworld2015.org) and various youth organisations:

Young people asked for education beyond primary schooling, not just formal learning but life skills and vocational training to prepare them for jobs. In countries where they have acquired good education and skills, they want access to decent jobs. They want opportunities to lift themselves out of poverty. (UN HLP 2013: 2)

This is balanced by a very strong rights narrative later in the text: "the ambition for the whole world should be the same: ... No child should ... be unable to read, write or do simple sums." (UN HLP 2013: 15)

\footnotetext{
${ }^{10}$ It is particularly striking that this paper, famous though it is, is the one cited rather than, for instance, more recent work by Patrinos that shows radically different sub-sectoral returns (Colclough, Kingdon and Patrinos 2010). See also the highly cited work of Hanushek and Woessmann (2008) on the economic impacts of cognitive skills (as opposed to education)- arguably more in keeping with the attempt to restress learning rather than years of schooling.
} 
There are hints too of the notions of state capacity, technological capability and the need for pro-poor professionals. For instance, it is noted that

Scientists and academics can make scientific and technological breakthroughs that will be essential to the post-2015 agenda. ... This requires universities, technical colleges, public administration schools and well trained, skilled workers in all countries. (UN HLP, 2013: 11)

However, such notions are never fully developed in the Report. Overall, higher education is largely ignored, even when there is talk about the "data revolution": in which there appears to be little or no role for Southern universities.

Overall, there is little sense of an exciting new agenda for education and development in the HLP Report whichever of these levels of analyses I employ. Yes, it is broader than the MDG goals, but less so than the EFA goals. At the same time, it is worryingly weak on the specific wordings and potential measurability of the sub-goals. Whilst it does restore the importance of learning, it is relatively underdeveloped on the close relationship this has with inequality and the continued challenge of getting the most marginalised into schooling and effective learning. Moreover, its reliance on very old rates of return data is an unsustainable basis for planning a forward-looking approach to "quality education and lifelong learning". This rather backward-looking stance is one in which education's economic and contraceptive purposes remain at the forefront and education continues to be seen as a mixture of silver bullet and black box.

\section{What are the policy challenges for education in the continuing post-2015 processes?}

Much of this section flows from the previous paragraph. I will focus particularly on three issues: the rise of learning outcomes, the relationship between quality and inequality and the shift beyond basic education.

The rise of learning outcomes clearly takes us back to what was understood at the time of the World Declaration on Education for All in 1990: that learning matters more than being in school. This understanding got lost as the EFA and MDG processes led to a narrow focus on getting children into school. Since 1990, and particularly in the run up to the 2015 deadline, there has been a growth of critiques of what has happened to learning quality. Data collated for the Brookings African Learning Barometer project (www.brookings.edu/research/interactives/africa-learning-barometer) reports that on tests of learning at the end of 4 or 5 years of primary schooling in 26 African countries, approximately $45 \%$ of African children are failing to meet basic learning outcomes in mathematics and the language of instruction. In Malawi, only $5 \%$ will have achieved basic mathematics learning outcomes. Even in the best-performing African countries, such as Cameroon and Swaziland, basic mathematics learning outcomes will not be met by four out of every ten children. At a more localised level, Watkins (2013) cites a survey in Sokoto State in Nigeria found that $80 \%$ of Grade 3 pupils could not read a single word.

A focus on learning is entirely appropriate, therefore. However, as the debate around the Brookings and UNESCO Institute of Statistic-convened Learning Metrics Taskforce shows, there are still difficult questions about measuring learning post-2015:

- What learning is important? Tests typically focus on a national or international language, mathematics, and sometimes science. Debates include the place of minority languages; whether this narrow set of subjects is appropriate; and the balance between cognition and other skills. Many responses to the learning metrics debate stress the importance of a broad learning definition. Yet, the draft goals look much narrower (cf. Burnett and Felsman 2012).

- How should learning outcomes be measured? Educationalists have long debated the mechanics of testing and the appropriateness of abstract one-off tests as 
opposed to continuous assessment of "real life problems". New technologies offer the potential for new testing approaches but there is relatively little evidence about what works in this regard.

- How can measurement enhance learning? Testing has long been criticised for distorting rather than enhancing learning. Although there has been much thinking about "assessment for learning", there is no feasible strategy yet for ensuring that the tests both generate data for global accountability processes and permit useful feedback down to the levels of classrooms and learners.

This focus on educational quality is to be welcomed. However, there is a potential danger that it takes attention away from matters of educational inequality. The analyses of the GMR team, the African Learning Barometer and the CREATE programme (http://www.create-rpc.org) all point to the challenges of getting children into schools and keeping them there, as well as to serious inequalities in learning achievement by various socioeconomic data amongst those who able to persevere. For Burnett and Felsman, of all the challenges of educational equity,

possibly most important, is that those who remain out of primary school are not forgotten in any move to expand or replace the education goals; they still represent some 10 percent of the global primary school age population, 40 percent of them are disabled, and a third live in low income countries affected by conflict. (Burnett and Felsman 2012: 11)

Many will welcome the broadening focus on education as a sector as opposed to the post-1990 obsession with primary schooling. Interestingly, this is not driven primarily by the international education and development policy community but rather by Southern Ministers of Education in response to the interest shown in this issue by growing domestic middle class constituencies (Burnett and Felsman 2012).

The different sub-sectors of education appear to faring differently in the post-2015 debates. It appeared initially that early childhood development was particularly well placed in Northern discourses given its interdisciplinarity, strong lobbying bodies and ability to combine rights and efficiency arguments. Yet, this momentum appears to have been lost. Secondary education is clearly a concern of countries with growing primary enrolments and rising incomes but there is little in the way of an organised constituency either in the advocacy or academic communities and it is not at all obvious how the subsector will fare in the continuing debates. Vocational education and training apparently has done well in the post-2015 process given the rise of a work agenda and sub-goals for both education and jobs. However, the field lacks strong lobbies or research visibility and sub-goal 3d is particularly weak, as noted above. As was already commented upon, literacy and higher education are largely absent from the HLP Report, although there are strands that the higher education community could draw upon. In this light, the new initiative of the Association of Commonwealth Universities - "The world in 2015; is higher education ready?" - may do something to raise higher education's profile in the development debate, even if it does not result in a sub-goal.

\section{What are the implications of these debates for the future of international education and development as a field of study?}

It is important to highlight that what little evidence that is provided for education's role in the HLP Report, and wider post-2015 debates is almost entirely drawn from the work of economists. The point here is not to criticise those producing this work but rather to challenge those working in the more sociological comparative education tradition. Many within that tradition would be uncomfortable with much of what is being said about education and development. They would be concerned about the absence of historical, cultural and political contexts from the storyline. They would worry about the orthodoxy that the technologies of educational improvement are straightforward. As Evans and 
Steven, who have been supporting Gordon Brown's role in the education and development debate, put it:

In focusing on social sectors like health and education, the MDGs prioritized areas of work where there was already extensive knowledge of what needed to be done: what was missing was the resources to do it. (Evans and Steven 2012: 4)

This largely paraphrases Jeffrey Sachs (2008: 301-2 - cf. McGrath 2010 for a critique of his naive account of education and development). Those from the sociological tradition would also worry that there is no sense of education's negative effects and that there are dangers in the inevitable instrumentalisation of education that results from such policy processes.

How then do we respond to these policy debates and to the challenges that lie in academic engagement with policy? It may be that the academic international education and development community is more comfortable in keeping these policy debates at a distance. If so, this may play against the strong educational research drive to engage in social science that makes a difference. More instrumentally, there are clear dangers here that certain routes to funding will likely be closed down.

If there is to be limited engagement with post-2015 then it is important that alternative ways of developing practices of research, action and dialogue be further strengthened. For Northern researchers, there is a strong case for these being strongly embedded in far more radical engagements with Southern actors, including teachers and learners.

However, it may be that there should be a stronger but more strategic engagement with the post-2015 debates. This may be around interdisciplinary dialogues around such issues as early childhood development, the role of professions in development or environmental sustainability. Engagement with the post-2015 debate would also require a careful analysis of how best to engage with the instrumentalised accounts of education that are dominant in the policy-advocacy arena, and the silence about education's violences. This would entail more strategic positions on the uses and dangers of social media.

At the same time, engagement with development studies as well as the development policy community requires a reappraisal of epistemological and methodological stances. Like many, I remain committed to the importance of contexts and the value of interpretative research drawing on the words and lifeworlds of individuals. However, I am concerned that we are not creative enough in both our communication of research from qualitative traditions and in our collaborations across methods and disciplines. This would need to be placed alongside critiques of inappropriate imposition of randomised control trials and depoliticised theories of change.

Are we comfortable in the irrelevance that Burnett identifies? At times, this appears to be a moral choice, but is it the right one? That is the greatest current challenge for academics working on international education and training.

\section{References}

Adams, A. 2012. The education link: why learning is central to the post-2015 global development agenda. Center for Universal Education Working Paper 8, Brookings Institution, Washington.

Argyris, C. and Schön, D. 1974. Theory in Practice. Jossey-Bass, San Francisco.

Barrett, A. 2011. A millennium learning goal for post-2015: a question of outcomes or processes. Comparative Education 47, 1, 119-133.

Brookings Institution 2013. Toward universal learning: what every child should learn. Downloaded

from: 
http://www.brookings.edu/ /media/Research/Files/Reports/2013/02/learning\%20metric s/LMTFRpt1TowardUnivrsILearning.pdf on 28/02/13.

Burnett, N. 2012. Are we becoming irrelevant? Reflections on the international education community's current approaches. Background note for DFID UKFIET dialogue 11 December 2012 on Education and Development to 2015 and Beyond. Results for Development Institute, Washington.

Burnett, N. and Felsman, C. 2012. Post-2015 education MDGs. Results for Development Institute, Washington.

Carton, M. 2013. Education, knowledge and evidence in the Post-2015 High-Level Panel Report: utopian, poetic or technocratic? All three! (Part 2). Downloaded from http://norrag.wordpress.com/2013/08/22/education-knowledge-and-evidence-in-thepost-2015-high-level-panel-report-utopian-poetic-or-technocratic-all-three-part-2/ on 22/08/13.

Centre for Research on the Wider Benefits of Learning. 2006. The wider benefits of learning. Brief No. RCB05-06. Department for Education and Skills, London.

Colclough, C., Kingdon, G. and Patrinos, H. 2010. The changing pattern of wage returns to education and its implications. Development Policy Review 28, 733-747.

Crossley, M., Broadfoot, P., and Schweisfurth, M., eds. 2007. Changing Educational Contexts. Routledge, London.

Crossley, M., and Watson, K. 2003. Comparative and International Research in Education. Routledge, London.

Evans, A. and Steven, D. 2013. What happens now? The post-2015 agenda after the High-level Panel. Downloaded from: http://cic.nyu.edu/sites/default/files/evans_steven_post2015_jun2013.pdf on 11/06/13.

Hanushek, E. and Woessmann, L. 2008. The role of cognitive skills in economic development. Journal of Economic Literature 46, 3, 607-668.

Hulme, D. and Wilkinson, R. 2012. Brave new world: global development goals after 2015. Brooks World Poverty Institute, BWPI Working Paper 168, Manchester.

International Institute for Sustainable Development 2013. Summary of the Global Meeting on Education in the Post-2015 Development Agenda. Downloaded from: http://www.iisd.ca/post2015/education on 27/08/13.

King, K. 1990. What happened at the World Conference in Jomtien? Norrag News 8.

King, K. 2013. Thank goodness! Education has made it to the finishing line in the global Post-2015 High Level Panel Olympics. Downloaded from http://norrag.wordpress.com/2013/05/31/thank-goodness-education-has-made-it-tothe-finishing-line-in-the-global-post-2015-high-level-panel-olympics on 31/05/13.

King, K. and McGrath, S. 2004. Knowledge for Development? Zed, London.

King, K. and Palmer, R. 2012. Education and skills in the post-2015 global landscape: history, context, lobbies and visions. Norrag Working Paper 1, Geneva.

King, K. and Palmer, R. 2013. Education and skills post-2015: what evidence, whose perspectives? Norrag Working Paper 6, Geneva.

King, K., Palmer, R. and Hayman, R. 2005. Bridging research and policy on education, training and their enabling environments. Journal of International Development 17, 6, 803-817.

McGrath, S. 2010. The role of education in development: an educationalist's response to some recent work in development economics. Comparative Education 46, 2, 237-253.

McGrath, S. 2013. Skills, work and development: initial reactions to the High Level Panel's Post-2015 vision. Downloaded from 
http://norrag.wordpress.com/2013/06/03/skills-work-and-development-initial-reactionsto-the-high-level-panels-post-2015-vision on 03/06/13.

Nussbaum, M. 2001. Women and Human Development. Cambridge University Press, Cambridge.

Open Working Group on Sustainable Development Goals 2013. Interim Report, 31 July 2013. Downloaded from http://www.un.org/ga/search/view_doc.asp?symbol=A/67/941\&Lang=E on 06/09/13.

Psacharopoulos, G. and Patrinos, H. 2002. Returns to investment in education: a further update. World Bank Policy Research Working Paper 2881, Washington.

Psacharopoulos, G. and Patrinos, H. 2004. Returns to investment in education: a further update. Education Economics 12, 2, 111-134.

Sachs, J. 2008. Common Wealth. Penguin, London.

Sustainable Development Solutions Network 2013. An Action Agenda for Sustainable Development. Report for the UN Secretary-General. Downloaded from http://unsdsn.org/files/2013/06/130613-SDSN-An-Action-Agenda-for-SustainableDevelopment-FINAL.pdf on 06/09/13.

UNESCO 1990. World Conference on Education for All (WCEFA). World Declaration on Education for All and Framework for Action to Meet Basic Learning Needs, UNESCO, Paris.

UN 2013. A Life of Dignity for All: Accelerating Progress Towards the Millennium Development Goals and Advancing the United Nations Development Agenda Beyond 2015. Report of the Secretary-General. 26th July, 2013. New York, UN. Downloaded from

http://www.un.org/millenniumgoals/pdf/A\%20Life\%20of\%20Dignity\%20for\%20All.pdf on $06 / 09 / 13$.

UN Global Compact 2013. Corporate Sustainability and the United Nations Post-2015 Development Agenda, Report to the United Nations Secretary-General, 17th July 2013. Downloaded

http://www.un.org/millenniumgoals/pdf/A\%20Life\%20of\%20Dignity\%20for\%20All.pdf on $06 / 09 / 13$.

UN High Level Panel 2013. A new global partnership: eradicate poverty and transform economies through sustainable development. Downloaded from: http://www.un.org/sg/management/pdf/HLP_P2015_Report.pdf on 30/05/13.

Vandemoortele, J. 2011. If not the Millennium Development Goals, then what? Third World Quarterly 32, 1, 9-25.

Watkins, K. 2013. Too little access, not enough learning: Africa's twin deficit in education. Downloaded from http://www.brookings.edu/research/opinions/2013/01/16africa-learning-watkins on 07/06/13.

\section{Principal blogs / websites consulted}

www.post2015.org

www.myworld2015.org

www.cafodpolicy.wordpress.com

www.chrisblattman.com

www.onthinktanks.org

www.worldwewant2015.org

www.brookings.edu/blogs

www.educationforallblog.org

www.owen.org/blog

www.efareport.wordpress.com 
www.thebrokeronline.eu

www.aidthoughts.org

www.ukfiet.org/cop

www.weizenegger.wordpress.com

www.simonmaxwell.eu

www.cgdev.org

www.theguardian.com/global-development

www.comparativist.org

www.aviewfromthecave.com

www.oxfamblogs.org/fp $2 p$

www.globaldashboard.org

www.odi.org.uk/opinion

www.bond.org/networker

www.norrag.wordpress.com

www.uncounted.org.uk

www.devpolicy.org

www.bigpushforward.net

www.nyudri.org/blog

www.resultsfordevelopment.org/blog

www.tracker.post2015.org 